Електронне наукове фахове видання "Ефективна економіка" включено до переліку наукових фахових видань України з питань економіки (Наказ Міністерства освіти і науки України від 11.07.2019 № 975) www. economy.nayka.com. ua | № 11, 2019 | 28.11.2019 p.

DOI: $10.32702 / 2307-2105-2019.11 .174$

UDC 338.121

\author{
V. Diachenko
}

Student of Economic Sciences Faculty, Petro Mohyla Black Sea National University

ORCID: 0000-0002-9963-362X

K. Netudyhata

Candidate of Economic Science, Associate Professor of Management Cathedra,

Petro Mohyla Black Sea National University

ORCID: 0000-0002-5322-4986

\title{
FINANCIAL STATE COMPARATIVE DIAGNOSTICS OF THE CONFECTIONERY INDUSTRY ENTERPRISES
}

\author{
В. С. Дяченко, \\ студент факультету економічних наук, \\ Чорноморський національний університет імені Петра Могили \\ К. Л. Нетудихата, \\ к.е.н., доиент, доцент кафедри менеджменту, \\ Чорноморський начіональний університет імені Петра Могили, м. Миколаїв

\section{ПОРІВНЯЛЬНА ДІАГНОСТИКА ФІНАНСОВОГО СТАНУ ПІДПРИЕМСТВ КОНДИТЕРСЬКОЇ ГАЛУЗІ}

The essence of the enterprise financial state diagnostics is investigated in the article. It is disclosed as an analysis and evaluation of certain indicators of an entity's activity based on the examination of reports in order to determine the current, future financial position, taking into account the complex consequences of management decisions. Diagnostics allows you to obtain reliable and complete information. The purpose of comparative diagnostics of enterprises is: detailing of the previously made diagnosis, research of violations and tendencies of their development, creation of a basis for making managerial decisions, formation of bases for adjusting the development's strategy of the organization.

The main indicators of financial condition of PrJSC "Kharkiv Biscuit Factory" and PJSC Lviv Confectionery Factory "Svitoch" for the period 2013-2018 years have been analyzed and identified. Some problems have been identified in the confectionery enterprises. Yes, the main assets of PrJSC "Kharkiv Biscuit Factory" are significantly worn out. PJSC Lviv Confectionery Factory "Svitoch" has low values of the absolute liquidity ratio, the terms of receivables and payables are rapidly increasing. Businesses are financially sound, business performance is quite high, profitability fluctuates significantly over time. Bankruptcy probabilities are estimated based on the bankruptcy models of Altman, Tuffler and Springgate. A low bankruptcy's probability of PrJSC "Kharkiv Biscuit Factory" and PJSC Lviv Confectionery Factory "Svitoch" was established. The main recommendations for improving the financial condition of both enterprises are outlined. Emphasis is placed on increasing their profitability. This implies an increase in the price of products, an increase in sales of profitable products, a decrease in the cost of sales, the level of administrative and sales costs, optimization of the range of products sold in order to increase the 
proportion of its more profitable types. Both companies need to develop and implement an effective financial strategy for sustainable development.

У статті досліджено сутність діагностики фінансового стану підприємства. Розкрито ї як аналіз та оцінку певних показників діяльності суб'єкта господарювання на основі вивчення звітів з метою встановлення поточного, окреслення майбутнього фінансового стану, враховуючи складні наслідки прийняття управлінських рішень. Діагностика дає змогу одержувати достовірну і повну інформацію. Метою порівняльної діагностики підприємств $\epsilon$ : деталізація раніше поставленого діагнозу, дослідження порушень та тенденцій їх розвитку, створення фундаменту для прийняття управлінських рішень, формування основ для коригування стратегії розвитку організачії.

Проаналізовано та досліджено основні показники фінансового стану ПрАТ «Харківська Бісквітна Фабрика» та ПАТ «Львівська Кондитерська Фабрика «Світоч» за період 20132018 рр. Виявлено певні проблемами у підприємств кондитерської галузі. Так, основні засоби ПрАТ «Харківська Бісквітна Фабрика» суттєво зношені. ПАТ «Львівська Кондитерська Фабрика «Світоч» має низькі значення коефічієнту абсолютної ліквідності, стрімко зростають терміни оборотності дебіторської та кредиторської заборгованості. Підприємства $\epsilon$ фінансово стійкими, показники ділової активності досить високі, рентабельність суттєво коливається в часі. Здійснено оиінку ймовірності їх банкрутства на основі моделей банкрутства Альтмана, Таффлера та Спрінгейта. Встановлено низьку ймовірність банкрутства ПрАТ «Харківська Бісквітна Фабрика» та ПАТ «Львівська Кондитерська Фабрика «Світоч».

Окреслено основні рекомендації щзодо поліпшення фінансового стану обох підприємств. Акцентовано увагу на підвищенні рентабельності їх діяльності. Це передбачає збільшення иіни на продукиію, нарощення обсягів продаж прибуткової продукиї̈, зменшення собівартості реалізованої продукиії, рівня адміністративних витрат та витрат на збут, проведення оптимізачії асортименту реалізованої продукиії з метою підвищення питомої ваги більш прибуткових ї̈ видів. Обом підприємствам необхідно розробити та реалізувати ефективну фінансову стратегію стійкого розвитку.

Keywords: diagnostics; financial state of the enterprise; financial indicators; financial analysis; liquidity; solvency; profitability; business activity; bankruptcy.

Ключові слова: діагностика; фінансовий стан підприємства; фінансові показники; фінансовий аналіз; ліквідність; платоспроможність; прибутковість; ділова діяльність; банкрутство.

Problem statement. At the present stage in Ukraine, with a conditionally stable economic situation in the country, constant changes in legislation, volatile exchange rate and inflation, objective assessment and diagnostics of financial state of enterprises play a paramount role in maintaining the stability of their activity. One of the most important problems which are facing modern Ukrainian enterprises is the lack of efficiency in managing financial resources in conditions of economic instability and crisis. Given that financial resources are a major factor in economic development and economic growth, the question arises about the need for a comprehensive assessment of their volume and structure. Diagnosis of financial condition allows to obtain an assessment, identify the factors and reasons for respective achieved state of an enterprise, as well as to prepare and justify the adoption of certain management decisions in relation to ensuring the effective management of financial resources and improving financial condition of the enterprise as a whole. For this reason, the question of the necessity to diagnose financial state of enterprises can be considered relevant.

Analysis of recent research and publications. Many domestic scientists have devoted their activities to the study of issues related to the diagnosis and development of ways to improve financial state of enterprises. Among the scientists who have paid considerable attention to this issue, we should mention such as E.M. Korotkov, B.M Litvin, V.V. Lukyanova, O.E. Naydenko, O.I. Oleksiuk, S.V. Prymak, M.V. Stelmach, G.A. Shvidanenko, I.O. Tarasenko etc. In spite of the considerable amount of work of scientists in the field of diagnostics of financial state of enterprises, the questions concerning the development of the ways of the most effective improvement of their financial state and diagnostics still remain insufficiently studied and relevant in conditions of socio-economic crisis in Ukraine, which has 
been going on for the last four years.

Purpose of research. The goals are to disclose the nature, methods of diagnostics of financial state of the confectionery industry enterprises and to outline the main recommendations for improving their financial condition.

Research outcomes. One of the most important areas of studying the enterprise's condition, especially in the study of the threat of crisis phenomena is the diagnostics of its financial state. Many domestic scientists have devoted their work to the study of financial diagnostics and provided their own definitions of its essence. For example, O.E. Naydenko determines that diagnostics of financial state of an enterprise is a complex of measures for assessing the strategic potential of an enterprise, the result of which should be diagnostics, which represents the definition and description of the current and prospective state of an enterprise, its main problems and ways of solving them [4, p. 163]. S.V. Prymak considers that diagnostics of financial state of an enterprise is a process of identification of the quality of financial condition of an enterprise and determining the factors that affect its financial parameters [7, p. 6]. E.M. Korotkov under diagnostics means the process of evaluation based on a set of methodological techniques for the state of an object, subject, phenomenon or control process, which allows them to identify weaknesses and "bottlenecks" [1, p. 52]. G.O. Shvydanenko and O.I. Oleksiuk define diagnostics of financial state of an enterprise, as a process of recognition and determination of negative (crisis) phenomena in the activity of an enterprise on the basis of observed local changes [9, p. 66]. V.V. Lukyanova and O.O. Labunets understand the diagnosis of financial state as a system of purposeful financial analysis aimed at identifying factors, causes of financial insolvency, establishing trends in their development and choosing the best ways to solve existing problems [3, p. 66]. In general, the diagnostics of financial state is a process of assessing the condition of an object using the method of rapid analysis and in-depth analysis, which will help to identify problems of financial state of an enterprise, the causes of their occurrence and identify methods for improving the situation. The importance of financial diagnostics is also caused by a wide range of users: owners, founders, shareholders, managers, investors, lenders, etc.

The main task of diagnostics of financial state is carrying out a complex analysis that will provide satisfaction of needs of both internal and external users. In the theory and practice of research on the activities of business entities, a large number of diagnostics methods of financial condition have been formed. All of them differ in the degree of the approach formalization to formalized (quantitative) and unformalized (qualitative or expert) [5, p. 209]. Diagnosis is advisable to perform on the indicators of property state, liquidity, solvency, business activity and profitability.

PrJSC "Kharkiv Biscuit Factory" is a leading enterprise representative of the confectionery industry of Kharkiv region in Ukraine. The main activity of the enterprise includes: production of breadcrumbs and dried biscuits; production of flour confectionery, cakes and pastries for long-term storage; production of cocoa, chocolate and sugar confectionery; wholesale of sugar, chocolate and sugar confectionery. The main indicators of financial state of the enterprise are given in Table 1.

The indicators of financial state of the PrJSC "Kharkiv Biscuit Factory"

\begin{tabular}{|c|c|c|c|c|c|c|c|c|}
\hline \multirow{2}{*}{ Indicator } & \multicolumn{6}{|c|}{ Value } & \multirow{2}{*}{$\begin{array}{l}\text { Standard } \\
\text { Value }\end{array}$} & \multirow{2}{*}{ Dynamics } \\
\hline & 2013 & 2014 & 2015 & 2016 & 2017 & 2018 & & \\
\hline $\begin{array}{l}\text { Depreciation ratio of } \\
\text { fixed Assets }\end{array}$ & 0,71 & 0,72 & 0,71 & 0,72 & 0,72 & 0,69 & Decrease & $-0,02$ \\
\hline \multicolumn{9}{|c|}{ Liquidity indicators } \\
\hline Overall liquidity & 5,13 & 9,00 & 7,09 & 7,22 & 7,39 & 7,43 & $>1$ & 2,30 \\
\hline Quick liquidity & 3,39 & 6,34 & 5,14 & 4,75 & 4,66 & 4,94 & $0,6-0,8$ & 1,55 \\
\hline Cash liquidity & 0,33 & 1,40 & 0,68 & 0,33 & 0,60 & 0,57 & $>0,2$ & 0,24 \\
\hline \multicolumn{9}{|c|}{ Solvency indicators } \\
\hline $\begin{array}{l}\text { Net working capital, } \\
\text { thous. UAH. }\end{array}$ & 272074 & 355613 & 483895 & 653139 & 688605 & 746841 & $>0$ & 474767 \\
\hline Autonomy ratio & 0,89 & 0,93 & 0,91 & 0,90 & 0,91 & 0,91 & $\geq 0,50$ & 0,02 \\
\hline \multicolumn{9}{|c|}{ Business activity indicators } \\
\hline $\begin{array}{l}\text { Accounts receivable } \\
\text { turnover ratio }\end{array}$ & 4,37 & 4,65 & 4,48 & 4,39 & 4,72 & 3,67 & Increase & $-0,7$ \\
\hline $\begin{array}{l}\text { Term of accounts } \\
\text { receivable turnover, days }\end{array}$ & 82,37 & 77,41 & 80,35 & 82,00 & 76,27 & 98,09 & Decrease & $+15,72$ \\
\hline $\begin{array}{l}\text { Accounts payable } \\
\text { turnover ratio }\end{array}$ & 16,73 & 27,98 & 25,00 & 26,26 & 27,13 & 25,83 & Increase & $+9,10$ \\
\hline $\begin{array}{l}\text { Term of accounts payable } \\
\text { turnover, days }\end{array}$ & 21,51 & 12,86 & 14,40 & 13,70 & 13,27 & 13,93 & Decrease & $-7,58$ \\
\hline \multicolumn{9}{|c|}{ Profitability indicators } \\
\hline
\end{tabular}




\begin{tabular}{|l|c|c|c|c|c|c|c|c|}
\hline Return on assets ratio, \% & 6,55 & 20,88 & 19,96 & 12,57 & 12,21 & 11,80 & Increase & 5,25 \\
\hline Return on equity ratio, \% & 7,33 & 22,36 & 22,00 & 13,90 & 13,47 & 12,99 & Increase & 5,66 \\
\hline Profitability ratio, \% & 4,70 & 14,17 & 11,19 & 7,07 & 7,24 & 7,77 & Increase & 3,07 \\
\hline $\begin{array}{l}\text { Profitability ratio of } \\
\text { products, \% }\end{array}$ & 5,51 & 17,24 & 13,17 & 8,16 & 8,77 & 9,16 & Increase & 3,65 \\
\hline
\end{tabular}

Source: compiled and calculated by the authors on the basis of financial statements of PrJSC "Kharkiv Biscuit

Factory" according to [6]

PJSC Lviv Confectionery Factory "Svitoch" is a leading enterprise representative of the confectionery industry of Lviv region in Ukraine. It is one of the oldest enterprises in the confectionery industry in Ukraine (56 years old already as of 2019) and nowadays Swiss corporation Nestlé owns the controlling stake of this confectionery factory. The main activity of PJSC LCF "Svitoch", according to the branch affiliation according to NACE-2010, is the production of breadcrumbs and dried biscuits; manufacture of flour confectionery, cakes, pastries, pies and biscuits of long-term storage (NACE 10.72); production of cocoa, chocolate and sugar confectionery: caramel, nougat, sweets, white chocolate (NACE 10.82); production of tea and coffee products (NACE 10.83). The headquarters of the PJSC LCF "Svitoch" is located in Tkatska street in Lviv. As for exports, this factory exports its products only to Moldova. The main indicators of financial state of the enterprise are given in Table 2.

The indicators of financial state of the PJSC LCF "Svitoch"

Table 2.

\begin{tabular}{|c|c|c|c|c|c|c|c|c|}
\hline \multirow{2}{*}{ Indicator } & \multicolumn{6}{|c|}{ Value } & \multirow{2}{*}{$\begin{array}{l}\text { Standard } \\
\text { Value }\end{array}$} & \multirow{2}{*}{ Dynamics } \\
\hline & 2013 & 2014 & 2015 & 2016 & 2017 & 2018 & & \\
\hline $\begin{array}{l}\text { Depreciation ratio of fixed } \\
\text { Assets }\end{array}$ & 0,43 & 0,45 & 0,48 & 0,55 & $0,48 \%$ & 0,50 & Decrease & $+0,07$ \\
\hline \multicolumn{9}{|c|}{ Liquidity indicators } \\
\hline Overall liquidity & 2,24 & 1,94 & 1,90 & 3,59 & 2,36 & 3,49 & $>1$ & $+1,25$ \\
\hline Quick liquidity & 1,25 & 1,15 & 0,91 & 2,54 & 1,69 & 2,59 & $0,6-0,8$ & $+1,34$ \\
\hline Cash liquidity & 0,041 & 0,048 & 0,34 & 0,24 & 0,031 & 0,15 & $>0,2$ & 0,109 \\
\hline \multicolumn{9}{|c|}{ Solvency indicators } \\
\hline $\begin{array}{l}\text { Net working capital, } \\
\text { thous. UAH. }\end{array}$ & 104991 & 97436 & 126465 & 555852 & 496205 & 630272 & $>0$ & 525281 \\
\hline Autonomy ratio & 0,79 & 0,79 & 0,70 & 0,62 & 0,71 & 0,80 & $\geq 0,50$ & 0,01 \\
\hline \multicolumn{9}{|c|}{ Business activity indicators } \\
\hline $\begin{array}{l}\text { Accounts receivable } \\
\text { turnover ratio }\end{array}$ & 15,21 & 10,55 & 13,98 & 8,11 & 4,14 & 3,78 & Increase & $-11,43$ \\
\hline $\begin{array}{l}\text { Term of accounts } \\
\text { receivable turnover, days }\end{array}$ & 23,66 & 34,12 & 25,75 & 44,38 & 86,95 & 95,2 & Decrease & $+71,54$ \\
\hline $\begin{array}{l}\text { Accounts payable } \\
\text { turnover ratio }\end{array}$ & 14,06 & 10,47 & 11,21 & 13,17 & 7,91 & 7,53 & Increase & $-6,53$ \\
\hline $\begin{array}{l}\text { Term of accounts payable } \\
\text { turnover, days }\end{array}$ & 25,6 & 34,38 & 32,1 & 27,33 & 45,5 & 47,8 & Decrease & $+22,2$ \\
\hline \multicolumn{9}{|c|}{ Profitability indicators } \\
\hline Return on assets ratio, $\%$ & 10,60 & 6,12 & 0,003 & 25,52 & 18,50 & 8,55 & Increase & $-2,05$ \\
\hline Return on Equity ratio, $\%$ & 13,39 & 7,07 & 0,005 & 40,66 & 26,0 & 10,69 & Increase & $-2,70$ \\
\hline Profitability ratio, $\%$ & 4,20 & 2,87 & 0,001 & 11,70 & 10,31 & 4,74 & Increase & $+0,54$ \\
\hline $\begin{array}{l}\text { Profitability ratio of } \\
\text { products, \% }\end{array}$ & 5,48 & 3,08 & 0,0017 & 14,46 & 12,08 & 5,19 & Increase & $-0,29$ \\
\hline
\end{tabular}

Source: compiled and calculated by the authors on the basis of financial statements of PJSC LCF "Svitoch" according to [6]

The data analysis of the Table 1 and Table 2 allows to make up an idea about financial state of PrJSC "Kharkiv 
Biscuit Factory" and PJSC LCF "Svitoch". The depreciation ratio describes the share of fixed assets that is written off on production costs. At the beginning of the studied period, as of December 31, 2013, the ratio of depreciation of fixed assets for PrJSC "Kharkiv Biscuit Factory" was 0.71 and at the end of the period (December 31, 2018) it decreased by 0.02 to 0,69 , which is a positive occurrence. As for PJSC LCF "Svitoch", the value of the depreciation ratio for the study period is significantly lower (0.42-0.50) compared to PrJSC "Kharkiv Biscuit Factory", but the dynamics is also negative and shows an increase of +0.07 as of 31.12. 2018 .

In the short term, the criterion for assessing financial state of an enterprise is its liquidity and solvency. The overall liquidity ratio is calculated as a share of the ratio of current assets to short-term liabilities and indicates whether an enterprise has sufficient funds that can be used to repay its short-term liabilities over a specified period. For PrJSC "Kharkiv Biscuit Factory" at the beginning of the period the value of the overall liquidity ratio was 5.13, while at the end of the period the value of the indicator increased to 7.43, increased by 2.30. No less significant increase in the value of the indicator occurred in the case of PJSC LCF "Svitoch", namely 1.25 units, compared with the initial value. Standard value is considered to be greater than one and therefore both enterprises have sufficient funds to pay off their short-term liabilities.

The quick liquidity ratio shows how much of current liabilities an enterprise is able to repay at the expense of the most liquid working capital: cash and cash equivalents, financial investments and accounts receivable. For PrJSC "Kharkiv Biscuit Factory", the value of the indicator at the end of the study period is 4.94, while in PJSC LCF "Svitoch" it is 2.59. The value of this indicator for both enterprises corresponds to the standard value of exceeding 0.6-0.8, which leads to the conclusion that the payment capabilities of both enterprises in terms of repayment of current liabilities are quite effective.

The cash liquidity ratio of PrJSC "Kharkiv Biscuit Factory" at the end of the study period (31.12.2018) is 0.57 and is higher than the minimum value, which corresponds to standard value for this indicator (0.2). For PJSC LCF "Svitoch", the cash liquidity ratio at the end of the period is 0.15 and is less than the standard value of this indicator (0.2), which indicates that factory has not enough cash (by the way, current financial investments during 2013-2018 years in enterprises are absent) to cover current liabilities.

The defining characteristic of an entity's financial state is its solvency. Solvency is determined by an entity's ability to quickly repay its short-term liabilities. At the end of the study period, net working capital of PrJSC "Kharkiv Biscuit Factory" is 746841 thousand UAH, which is 2.75 times more than the value at the beginning of the period (272074 thousand UAH). This indicates that the company has its own funds, because standard value of the indicator is $>$ 0 . The situation is even better in PJSC LCF "Svitoch": an increase of more than 6 times (104991 thousand UAH at the end of 2013 compared to 630272 thousand UAH at the end of 2018).

At the end of the period, the autonomy ratio for PrJSC "Kharkiv Biscuit Factory" and PJSC LCF "Svitoch" is 0.91 and 0.80 respectively, which indicates that both enterprises are financially independent from external sources of financing their activities. Business activity of the company in the financial aspect is manifested primarily in the speed of turnover of its funds. Business activity analysis is to study the levels and dynamics of various turnover ratios.

Accounts payable turnover ratio reflects an increase or decrease in the commercial credit given to an enterprise. An increase in the ratio means an increase in the rate of payment of the company's debt, a decrease - an increase in credit purchase. For PrJSC "Kharkiv Biscuit Factory", this indicator increased by 9.1 units, and the term of accounts payable turn over decreased by 7.5 days to 13.93 days, which indicates a decrease in the number of the enterprise credit, the trend is positive. However, the indicator of term of accounts receivable turnover for PJSC "Kharkov Biscuit Factory" is not well, as at the end of the period it increased by 15.72 days to 98.09 days, which indicates a slower process of debt repayment by the debtors PJSC "Kharkov Biscuit Factory".

However, the opposite situation occurs in the case of PJSC LCF "Svitoch", whose term of accounts payable turnover has increased by 22.2 days (up to 47 days) and term of accounts receivable turnover by up to 71.5 days (up to 95 days). Both trends are negative and indicate both an increase in the volume of accounts payable by PJSC LCF "Svitoch" and a steady tendency to delay the repayment of debt by the debtors of PJSC LCF "Svitoch", judging by the total value of the indicator at the end of the period. This may indicate that PJSC LCF "Svitoch" has become more loyal in cooperation with its debtors regarding the period and terms of their debt repayment. It can be predicted that such a move by PJSC LCF "Svitoch" is driven by the focus on stimulating the growth of the company's customers, maintaining competitiveness in the field of its activity, and accordingly - improving the factory's reputation in the context of working with clients. In terms of profitability indicators, for both enterprises, they show a steady positive upward trend at the end of the study period compared to the beginning of the period.

Summarizing the above, it can be argued that both PrJSC "Kharkiv Biscuit Factory" and PJSC LCF "Svitoch" have a considerable margin of financial stability and, in the most part, financial indicators that are relevant to the standard values, which shouldenable both enterprises to prevent bankruptcy.

In order to prevent bankruptcy, many economic models have been developed in practice to help identify its manifestations in the early stages. In foreign countries, the most common assessment of the possibility of a crisis financial state of an enterprise and its tendency to bankruptcy is the use of econometric models of Altman, Springate and Taffler.

The Altman model is one of the first models of an enterprise probability bankruptcy analysis to be based on discriminatory analysis. The Altman model is an algorithm for assessing the bankruptcy risk of an insolvent company, based on a comprehensive accounting of the most important indicators that help to identify the crisis financial state of an enterprise: profitability, leverage, liquidity, solvency [8, p. 194]. The calculation of the Altman model is as follows: 


$$
Z=1,2 x_{1}+1,4 x_{2}+3,3 x_{3}+0,6 x_{4}+x_{5},
$$

where $\mathrm{Z}$ - integral indicator of the threat level of bankruptcy;

$\mathrm{x}_{1}-$ net working capital / total amount of assets;

$\mathrm{x}_{2}$ - retained earnings / total amount of assets;

$\mathrm{x}_{3}-$ net profit / total amount of assets;

$\mathrm{x}_{4}$ - equity / liabilities;

$\mathrm{x}_{5}-$ net revenue / total amount of assets.

The Springate model envisages the development of an integral indicator that helps to assess the probability of recognition of an enterprise as a bankrupt. It is important that the accuracy of this model is quite high and is over $90 \%$ [8, p. 195]. The formula for the calculation is as follows:

$$
\mathrm{Z}=1,03 \times \mathrm{a}+3,07 \times \mathrm{b}+0,66 \times \mathrm{c}+0,4 \times \mathrm{d},
$$

where $\mathrm{Z}$ - integral indicator of the threat level of bankruptcy;

a - net working capital / total asset value;

$\mathrm{b}$ - earnings before interest $\&$ tax/ total asset value;

c - pre-tax profit/ short-term liabilities;

$\mathrm{d}-$ sales volume / total asset value.

Also in international practice, the Taffler model of bankruptcy probability assessment is quite widely used. The Taffler model is limited by a small number of indicators that provide high accuracy of results with minimal effort.

Calculation formula:

$$
Z=0,53 x_{1}+0,13 x_{2}+0,18 x_{3}+0,16 x_{4},
$$

where $\mathrm{Z}$ - integral indicator of the threat level of bankruptcy;

$\mathrm{x}_{1}$ - operating income before taxes / short-term liabilities;

$\mathrm{x}_{2}$-current assets / amount of liabilities;

$\mathrm{x}_{3}$ - short-term liabilities / amount of assets;

$\mathrm{x}_{4}-$ net income / amount of assets.

The actual values of the given coefficients of the Altman, Springate, and Taffler models for the PrJSC "Kharkiv Biscuit Factory" are given in Table 3.

Actual values of the given coefficients of the Bankruptcy Probability Analysis models of

\begin{tabular}{|c|c|c|c|c|c|c|}
\hline Model & \multicolumn{6}{|c|}{ Coefficients } \\
\hline \multicolumn{7}{|c|}{ PrJSC "Kharkiv Biscuit Factory" } \\
\hline \multirow{2}{*}{ Altman's } & $\mathrm{x}_{1}$ & $\mathrm{X}_{2}$ & $\mathrm{X}_{3}$ & $\mathrm{x}_{4}$ & $\mathrm{X}_{5}$ & $\mathrm{Z}$ \\
\hline & 0,57 & 0,79 & 0,12 & 9,76 & 1,77 & 9,812 \\
\hline \multirow{2}{*}{ Springate's } & $\mathrm{a}$ & $\mathrm{b}$ & $\mathrm{c}$ & $\mathrm{d}$ & - & - \\
\hline & 0,57 & 0,12 & 1,59 & 1,77 & - & 2,71 \\
\hline \multirow{2}{*}{ Taffler's } & $\mathrm{x}_{1}$ & $\mathrm{x}_{2}$ & $\mathrm{X}_{3}$ & $\mathrm{x}_{4}$ & - & - \\
\hline & 1,30 & 6,98 & 0,003 & 1,77 & - & 1,880 \\
\hline \multicolumn{7}{|c|}{ PJSC LCF "Svitoch" } \\
\hline \multirow{2}{*}{ Altman's } & $\mathrm{X}_{1}$ & $\mathrm{X}_{2}$ & $\mathrm{X}_{3}$ & $\mathrm{X}_{4}$ & $\mathrm{X}_{5}$ & $\mathrm{Z}$ \\
\hline & 0,57 & 0,79 & 0,12 & 9,76 & 1,77 & 9,812 \\
\hline \multirow{2}{*}{ Springate's } & $\mathrm{a}$ & $\mathrm{b}$ & $\mathrm{c}$ & $\mathrm{d}$ & - & - \\
\hline & 0,57 & 0,12 & 1,59 & 1,77 & - & 2,71 \\
\hline \multirow{2}{*}{ Taffler's } & $\mathrm{x}_{1}$ & $\mathrm{x}_{2}$ & $\mathrm{x}_{3}$ & $\mathrm{x}_{4}$ & - & - \\
\hline & 1,30 & 6,98 & 0,003 & 1,77 & - & 1,880 \\
\hline
\end{tabular}

Table 3. PrJSC "Kharkiv Biscuit Factory" and PJSC LCF "Svitoch"

Source: compiled by the authors based on [6]

Bankruptcy standard values by the models of Altman, Springate and Taffler are given in Table 4. 
Table 4.

Probability of bankruptcy by the models of Altman, Springate and Taffler

\begin{tabular}{|c|c|}
\hline Z-score & Probability of bankruptcy \\
\hline $\mathrm{Z}<1,81$ & Altman's Model \\
\hline $1,81 \leq \mathrm{Z}<2,77$ & $30-100 \%$ \\
\hline $2,77<\mathrm{Z}<2,99$ & $35-50 \%$ \\
\hline $\mathrm{Z} \geq 3$ & $15-20 \%$ \\
\hline \multicolumn{2}{|c|}{ Springate's Model } \\
\hline \multicolumn{2}{|c|}{ Taffler's Model } \\
\hline $\mathrm{Z}>0,3$ & High \\
\hline $0,3<\mathrm{Z}<0,2$ & Low \\
\hline $\mathrm{Z}<0,2 \quad$ Source: compiled by the authors based on $[8]$ \\
\hline
\end{tabular}

Analyzing the above calculations and equating them to the specified values of the Altman, Springate and Taffler models, it can be argued that there are no bankruptcy probabilities for both PrJSC "Kharkiv Biscuit Factory" and PJSC LCF "Svitoch", since all values are higher than the threshold indicated in Table 4 standards for low probability of bankruptcy. Summarizing the value of all these models, which characterize the degree of probability of bankruptcy at the enterprise, it can be argued that these entities are not threatened by the phenomenon of bankruptcy. However, even if one makes a comparison, the PJSC LCF "Svitoch" is closer to bankruptcy than PrJSC "Kharkiv Biscuit Factory".

Conclusions. Diagnostics of financial state of an enterprise allows to obtain reliable and complete information, which serves as a basis for the development and adoption of effective management decisions in the further activity of an enterprise. That is, timely diagnostics makes it possible to identify not only the present financial state of an enterprise, but also the reasons that hinder its successful development. As a result of diagnosing financial state of PrJSC "Kharkiv Biscuit Factory" in 2013-2018, it was found that, compared to PJSC LCF "Svitoch", a high degree of depreciation of fixed assets is a significant problem of the enterprise (0.69-0.72 vs. 0.42-0.50). Therefore, one of the main tasks for PrJSC "Kharkiv Biscuit Factory" should be an upgrade of fixed assets on an innovative basis. The main problem of PJSC LCF "Svitoch" activity is rapid increase in term of accounts receivable and payable turnover. It can advised to the management of the enterprise to be less loyal in matters of cooperation with their debtors regarding the period and the conditions of their repayment of their debts, in order to reduce the growth of current debts and liabilities of the PJSC LCF "Svitoch" itself.

Another significant problem identified is the decrease in profitability indicators of PrJSC "Kharkiv Biscuit Factory" in 2016 compared to their respective values in 2014, and PJSC LCF "Svitoch" in 2015, compared to 2013. In order to increase the profitability of both enterprises, it can be advised to: increase the prices of products; increase sales of profitable products; reduce the cost of products sold, the level of administrative and sales costs; optimize the range of products sold in order to increase the proportion of its more profitable types.

It should be noted that both PrJSC "Kharkiv Biscuit Factory" and PJSC LCF "Svitoch" have a considerable margin of financial stability, business activity indicators are quite high. The probability of bankruptcy of both entities is low (according to the models of Altman, Springate and Taffler). Today, it is appropriate for both enterprises to develop and implement an effective sustainable financial strategy that is both adequate in terms of goals and priorities.

\section{References.}

Russia.

1. Korotkov, Je. M. (2008), Antikrizisnoe upravlenie: uchebnik [Crisis management], INFRA-M, Moskva,

2. Lytvyn, B.M., Stel'makh, M.V. (2008), Finansovyj analiz: navch. posib. [Financial analysis], KhajTek Pres, Kyiv, Ukraine.

3. Luk'ianova, V.V, Labunets', O.O. (2018), "Diagnosis of the financial condition of the enterprise and ways to improve it”, Pryazovs'kyj ekonomichnyj visnyk, vol. 2(07), pp. 66-69.

4. Najdenko, O.Ye. (2005), "Methods of diagnostics of the state of the internal environment of the enterprise", Visnyk Skhidnoukrains'koho natsional'noho universytetu im. V.Dalia, vol. 2 (84), pp. 162-170.

5. Netudykhata, K.L., Truschenko, I.S. (2018), "Theoretical principles of the financial state diagnostics of the enterprise in the crisis management system", Skhidna Yevropa: ekonomika, biznes ta upravlinnia, vol. 1(12), pp. 207210.

6. Official site of the Stock Market Infrastructure Development Agencies of Ukraine (2019), available at: http://www.ukrstat.gov.ua/ (Accessed 20 Oct. 2019).

7. Priymak, S.V. (2007), "The financial state diagnosis of the enterprise in the controlling system" Ph.D. Thesis, Money, finance and credit, Institute of Economics and Forecasting, Kyiv, Ukraine.

8. Tarasenko, I.O., Liubenko, N.M. (2015), Finansy pidpryiemstv: pidruchnyk [Business Finance], Kyiv, KNUTD, Ukraine. 
9. Shvydanenko, H.O., Oleksiuk, O.I. (2002), Suchasna tekhnolohiia diahnostyky finansovo-ekonomichnoi diial'nosti pidpryiemstva: Monohrafiia [Modern technology of diagnostics of financial and economic activity of the enterprise]. KNEU, Kyiv, Ukraine.

\section{Література.}

1. Коротков Э.М. Антикризисное управление: учебник. Москва, ИНФРА-М, 2008. 620 с.

2. Литвин Б.М., Стельмах М.В. Фінансовий аналіз: навч. посіб. Київ, ХайТек Прес, 2008. 336 с.

3. Лук'янова В.В., Лабунець О.О. Діагностика фінансового стану підприємства та шляхи його поліпшення. Приазовський економічний вісник. 2018. № 2(07). С. 66-69.

4. Найденко О.Є. Методика діагностики стану внутрішнього середовища підприємства. Вісник Східноукраїнського національного університету ім. В.Даля. 2005. №2 (84). С. 162-170.

5. Нетудихата К.Л., Трущенко І.С. Теоретичні засади діагностики фінансового стану підприємства в системі антикризового управління. Східна Європа: економіка, бізнес та управління. 2018. №1(12). С. $207-210$.

6. Офіційний сайт Агентства 3 розвитку інфраструктури фондового ринку України, URL: https://smida.gov.ua

7. Приймак С.В. Діагностика фінансового стану підприємства в системі контролінгу: автореф. дис. канд. екон. наук: 08.00.08. Київ, Ін-т економіки та прогнозування НАН України, 2007. 23 с.

8. Тарасенко I.О., Любенко Н. М. Фінанси підприємств: підручник. Київ, КНУТД, 2015. 360 с.

9. Швиданенко Г.О., Олексюк О.І. Сучасна технологія діагностики фінансово-економічної діяльності підприємства: Монографія. Київ, Вид-во КНЕУ, 2002. 192 с. 